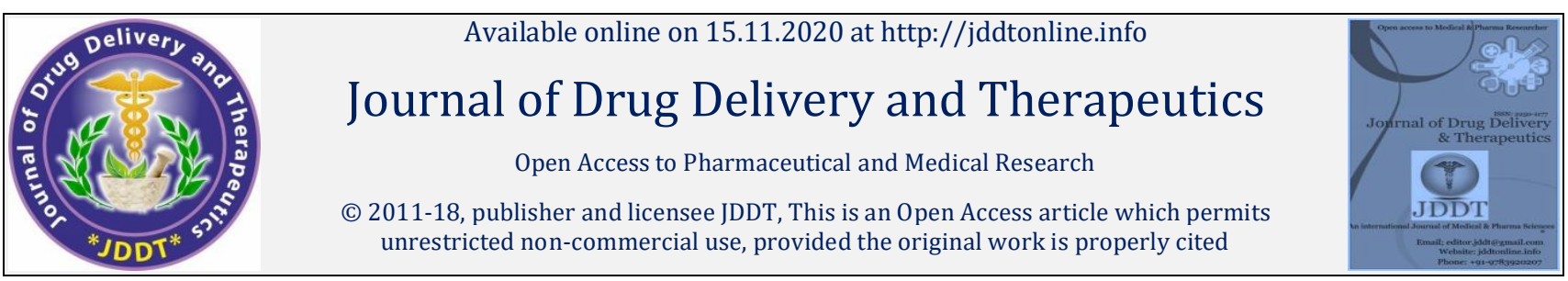

Open $\odot$ Access

Research Article

\title{
Development and Validation of RP-HPLC Method for Estimation of Amlodipine Besylate and Celecoxib in Pharmaceutical Formulation
}

\author{
Nagamani P*, Manjunath SY, Hemant Kumar T \\ Department of Pharmaceutical Analysis, Srikrupa Institute of Pharmaceutical Sciences, Siddipet-502 277 (TS)
}

\begin{abstract}
A simple, precise, accurate, and rapid reverse phase-high performance liquid chromatography (RP-HPLC) method with UV-Visible detector has been developed and subsequently validated for the simultaneous determination of amlodipine besylate(AML) and celecoxib(CEL) in their combined tablet dosage form. The separation was based on the use of a Flowrosil $\mathrm{C}_{18}$ analytical column $(250 \times 4.6 \mathrm{~mm}$, i.d., $5 \mu \mathrm{m})$. The mobile phase consisted of a mixture of 80 volumes of acetonitrile and 20 volumes of water. The chromatography was performed by isocratic elution at a flow rate of $1 \mathrm{~mL} / \mathrm{min}$. Analytes were detected at $250 \mathrm{~nm}$, with linear calibration curves at concentration ranges of 2-12 $\mu \mathrm{g} / \mathrm{ml}$ and $50-300$ $\mu \mathrm{g} / \mathrm{ml}$ for AML and CEL respectively. The retention time of AML and CEL were 1.98 and 3.15 min respectively. The recoveries obtained were 99.46-101.36\% for AML, $99.57-101.42 \%$ and $99.96-100.87 \%$ for CEL. The method was validated according to International conference of harmonisation guidelines in terms of accuracy, precision, specificity, robustness, limits of detection and quantitation, and other aspects of analytical validation. The developed method was applied successfully for HPLC analysis of commercial pharmaceutical products including AML and CEL.
\end{abstract}

Keywords: Amlodipine besylate; Celecoxib; RP-HPLC.

Article Info: Received 11 Sep 2020; $\quad$ Review Completed 19 Oct 2020; $\quad$ Accepted 25 Oct 2020; Available online 15 Nov 2020

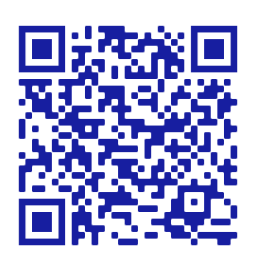

Cite this article as:

Nagamani P, Manjunath SY, Hemant Kumar T, Development and Validation of RP-HPLC Method for Estimation of Amlodipine Besylate and Celecoxib in Pharmaceutical Formulation, Journal of Drug Delivery and Therapeutics. 2020; 10(6):31-36 http://dx.doi.org/10.22270/jddt.v10i6.4521

*Address for Correspondence:

Nagamani P, Department of Pharmaceutical Analysis, Srikrupa Institute of Pharmaceutical Sciences, Siddipet-502 277 (TS)

\section{INTRODUCTION}

Amlodipine Besylate(AML) is the besylate salt of amlodipine chemically, 3-ethyl 5-methyl 2-[(2-aminoethoxy)methyl]-4(2-chlorophenyl)-6-methyl-1,4-dihydropyridine-3,5-

CELarboxylate-benzene sulfonic acid is a synthetic dihydropyridine with antihypertensive and antianginal effects $^{1}$. AML inhibits the influx of extracellular calcium ions into myocardial and peripheral vascular smooth muscle cells, thereby preventing vascular and myocardial contraction. These results in a dilatation of the main coronary and systemic arteries, decreased myocardial contractility, increased blood flow and oxygen delivery to the myocardial tissue, and decreased total peripheral resistance ${ }^{2}$. This agent may also modulate multi-drug resistance (MDR) activity through inhibition of the pglycoprotein efflux pump. Celecoxib (CEL) 4-[5-(4Methylphenyl)-3-(trifluoromethyl) pyrazol-1-yl] benzenesulfonamide is nonsteroidal anti-inflammatory drug. Celecoxib selectively inhibits cyclo-oxygenase-2 activity (COX-2); COX-2 inhibition may result in apoptosis and a reduction in tumor angiogenesis and metastasis ${ }^{3,4}$. Both Drugs are official in $\mathrm{IP}^{5}$ and $\mathrm{BP}^{6}$. With hypertension osteoarthritis $(\mathrm{OA})$ is another cause of disability in elderly populations. The prevalence of $\mathrm{OA}$ is increasing, and many studies reported that hypertension is self-regulating risk factor for the occurrence of knee OA. Elderly and obese patients are generally diagnosed as having both hypertension and OA. Hence, a fixed-dose oral formulation of amlodipine and celecoxib has been approved for the control of hypertension and OA. AML (Fig. 1) is a long-acting dihydropyridine derivative calcium-channel blocker utilized for the management of hypertension and angina. Celecoxib (CEL; Fig. 2) is a selective cyclooxyginase-2 inhibitor used for the management of chronic inflammatory and pain problems, such as rheumatoid arthritis and OA. CEL is preferred over other regular nonsteroidal anti-inflammatory drugs (NSAIDs) due to its protective action on the gastrointestinal tract and kidney, as it conserves the physiologically beneficial COX-1 in these organs. In addition, it has less of an effect on hypertension when compared to naproxen, ibuprofen, and other NSAIDs. Many analytical 
methods reported for estimation AML either single or in combination with other drugs in API, pharmaceutical formulations and biological fluids includes spectrophometric 7-11 and HPLC12-14. For CEL few analytical methods reported for its estimation in pharmaceutical formulation either alone or in combination with other drugs which includes spectrophometric ${ }^{15}$ and HPLC16-18. Literature survey revealed few UV19-22 and HPLC ${ }^{23-24}$ methods methods reported for simultaneous estimation of AML and CEL in their dosage forms. Obviously, HPLC methods are superior in compared to spectrophotometric methods in simultaneous quantification. The reported HPLC methods have drawbacks of long retention times for drugs and complex mobile phase composition. As long retention time need a more consumption of mobile phase. So, there is a need of a HPLC method, where the retention time is less and mobile phase having simple in composition.

The purpose of this study was to develop a simple, rapid, precise, and accurate RP-HPLC method for the simultaneous estimation of these drugs in combined tablet dosage form.
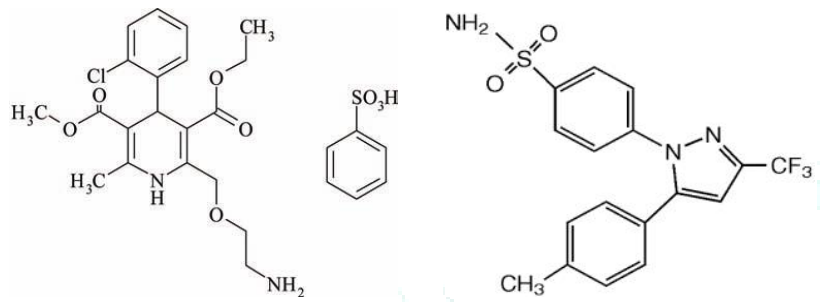

Figure 1: Structure of AML Figure 2: Structure of CEL

\section{EXPERIMENTAL}

\section{Materials and Reagents}

Samples of Amlodipine Besylate and Celecoxib were obtained as gift sample from RA Chem Ltd, Hyderabad Pvt. Ltd (India). Tablet formulation CONSENSI containinng Amlodipine Besylate (5 mg) and Celecoxib(200 mg) were procured from commercial market. All the solutions were protected from light and were analyzed on the day of preparations. Glass wares used in each procedure were soaked overnight in a mixture of chromic acid and sulphuric acid rinsed thoroughly with double distilled water and dried in hot air oven. All the reagents were of analytical-reagent (AR) grade unless stated otherwise. Millipore water, HPLC grade methanol, acetonitrile were procured from Merck, India. Borosilicate (Class - A) glass wares were used.

\section{Instrumentation}

HPLC analysis was carried out using a reversed-phase column-based high performance liquid chromatography method (CYBERLAB, USA). The system consisted of LC-P100 binary pump, and a variable wavelength programmable LCUV 100 detector. Rheodyne injector fitted with a $20 \mu \mathrm{L}$ loop was used and data were recorded and analysed using LC solutions software version 4.0. Weighing was done on Digital Microbalance (SHIMADZU AUX 220). Ultra sonicator (Citizen ultra sonicator) was used for sonicating the drug and sample solution.

\section{Chromatographic Conditions}

The chromatographic separation was carried out on the Flowrosil C18 column ( $250 \times 4.6 \mathrm{~mm}$ i.d, $5-\mu \mathrm{m}$ particle).The mobile phase consisted of acetonitrile: water in the ratio of 80: $20 \mathrm{v} / \mathrm{v}$. The injection volume was $20 \mu \mathrm{L}$ and eluents detected at $250 \mathrm{~nm}$ with the flow rate $1.0 \mathrm{ml} / \mathrm{min}$. The HPLC system was operated at a room temperature of $30^{\circ} \mathrm{C}$.

\section{Preparation of Stock and Standard Solutions}

A sample of $25 \mathrm{mg}$ of each drug is weighed and transferred to a $25-\mathrm{ml}$ volumetric flask; $15 \mathrm{ml}$ of acetonitrile is added, and the solution is sonicated for $15 \mathrm{~min}$. The volume is made up to the mark with acetonitrile to obtain a stock solution of $1000 \mu \mathrm{g} / \mathrm{ml}$. From the standard stock solutions, $2.5 \mathrm{ml}$ are with-drawn and transferred to $25 \mathrm{ml}$ volumetric flasks, and the volume is made up to the mark with mobile phase to obtain working standard solutions of $100 \mu \mathrm{g} / \mathrm{ml}$.

\section{Preparation of Sample Solution}

The assay of commercial tablets was established with present chromatographic condition developed and it was found to be more accurate and reliable. To determine the content of AML and CEL in conventional tablet (5 mg AML/200 mg CEL) twenty tablets were weighed; their mean weight was determined and was finely powdered. Tablet powder equivalent to $10 \mathrm{mg}$ AML with relevant quantities of CEL was weighed and transferred to a $100 \mathrm{ml}$ volumetric flask, extracted for 30 mins with acetonitrile and volume was made up to $100 \mathrm{ml}$ with acetonitrile. $0.5 \mathrm{ml}$ of above solution was taken in $10 \mathrm{ml}$ volumetric flask and volume was made up to $10 \mathrm{ml}$ with mobile phase, and final solution (5 $\mu \mathrm{g}$ AML, $200 \mu \mathrm{g} \mathrm{CEL} / \mathrm{ml}$ ) was filtered through $0.45 \mu$ millipore filter and it was analyzed by HPLC system.

\section{Method Validation}

The developed method was validated according to the ICH guideline 25 . Method validation included system suitability test, stability, and the validation parameters involving specificity, linearity, accuracy, precision and robustness.

\section{RESULTS AND DISCUSSION}

\section{Optimization of chromatographic condition}

From the UV spectra it was observed that AML and CEL have a considerable absorbance at $250 \mathrm{~nm}$. So, $250 \mathrm{~nm}$ was selected as detection wavelength. Various combination of mobile phase consisting of acetonitrile, methanol and water. Preliminary experiments were carried out with different combinations of acetonitrile or methanol with water was to separate the peaks of AML and CEL and to obtain suitable retention times and peak symmetry. Finally, a mobile phase consisting of acetonitrile and water in the ratio of $80: 20, \mathrm{v} / \mathrm{v}$ and Flowrosil C18 column (250 x $4.6 \mathrm{~mm} ; 5 \mu \mathrm{m})$ were selected to achieve good resolution and acceptable peak symmetry. Flow rates between 0.5 and $1.2 \mathrm{ml} / \mathrm{min}$ were tried. Flow rate of $1.0 \mathrm{ml} / \mathrm{min}$ was observed to be enough to get both the drugs eluted within less than $10 \mathrm{~min}$. The optimized chromatogram Fig. 3.The retention time of AML and CEL were found to be 1.98 and 3.15 min respectively.

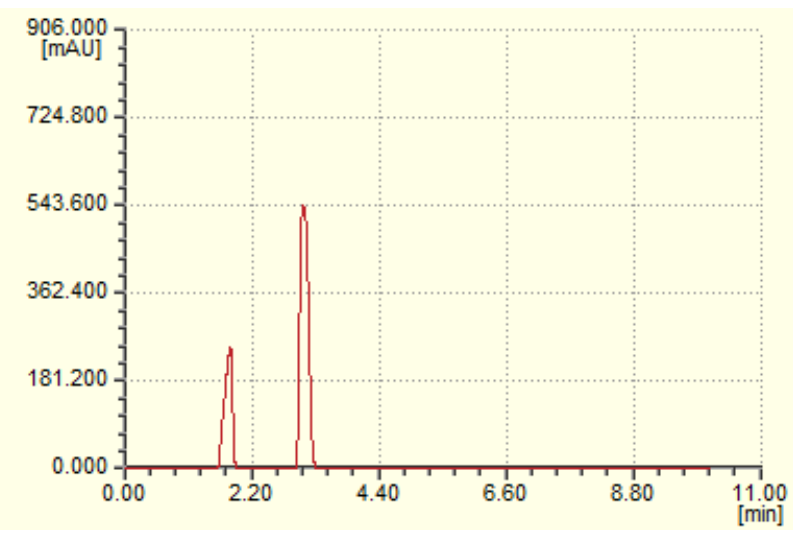

Figure 3: Chromatogram of standard solution AML and CEL from binary mixture. 


\section{Method Validation}

\section{System Suitability Test}

After setting the optimum conditions, system suitability parameters for the developed method were determined and compared with recommended limits. System suitability parameters of the method were demonstrated in Table 1. According to results, all of the system suitability parameters were within the recommended limits and the method was found to be suitable for the analysis.

Table 1 Results of system suitability test $(n=6)$

\begin{tabular}{|c|c|c|c|}
\hline Parameter & Criteria & AML & CEL \\
\hline Capacity factor $(k)$ & $k^{\prime}>2$ & 2.824 & 1.321 \\
\hline Tailing factor $(T)$ & $\mathrm{T}<2$ & 6380 & 8482 \\
\hline Theoretical plates $(N)$ & $\mathrm{N}>2000$ & - & 4.02 \\
\hline Resolution $(R s)$ & $R s>2$ & 0.74 & 0.52 \\
\hline \% RSD (peak area) & \% RSD $\leq 1$ & & \\
\hline
\end{tabular}

\section{Stability of sample solution}

The sample solution stability was analyzed by injecting the same solution at $0,12,24$, and $48 \mathrm{~h}$. Identical change was not observed in the developed method. Also, results were found within acceptable limits (RSD $<2$ ), which are summarized in Table 2.

Table 2: Stability data of AML and CEL (standard solutions)

\begin{tabular}{|l|c|c|c|c|}
\hline \multirow{2}{*}{ Time (hr) } & \multicolumn{2}{|c|}{ Assay (\%) } & \multicolumn{2}{c|}{ \% Difference } \\
\cline { 2 - 5 } & AML & CEL & AML & CEL \\
\hline Initial & 100.08 & 99.96 & --- & 0.05 \\
\hline After $12 \mathrm{hr}$ & 100.02 & 99.92 & 0.21 & 0.34 \\
\hline After $24 \mathrm{hr}$ & 99.87 & 99.62 & 0.92 & 0.93 \\
\hline After $36 \mathrm{hr}$ & 99.16 & 99.03 & 1.76 & 1.85 \\
\hline After $48 \mathrm{hr}$ & 98.32 & 98.11 & & - \\
\hline
\end{tabular}

\section{Linearity}

The linearity ranges for AML and CEL were found to be 2-12 $\mu \mathrm{g} / \mathrm{ml}$ and $50-300 \mu \mathrm{g} / \mathrm{ml}$ respectively. The linear regression equation for AML was found to be $7486.5 \mathrm{x}$ - 55 with correlation coefficient 0.9993 . The linear regression equation for CEL was found to be 3080.6 x- 18600 with

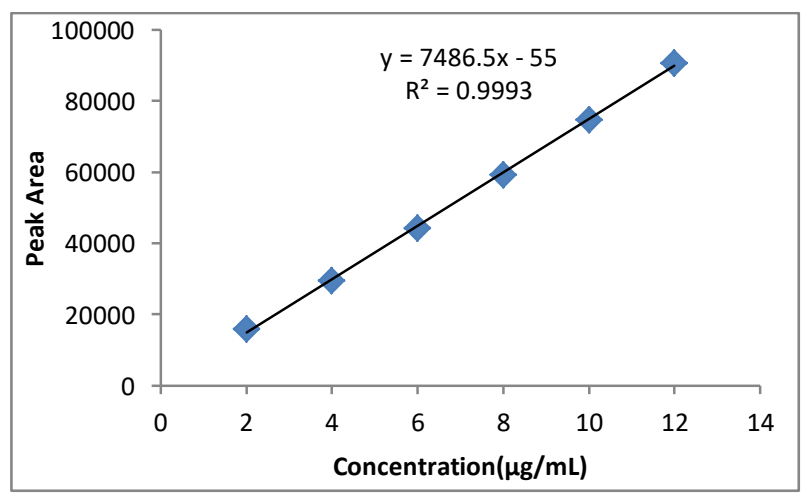

Figure 4: Calibration curve of AML correlation coefficient 0.9991.The data for AML and CEL was shown in Table 3. The calibration curve of AML and CEL were shown in Fig. 4 and Fig. 5 respectively. Linear regression of data from the calibration curve indicated a linear response over the concentration range of both drugs. The curve can therefore be used for determination of AML and CEL in pharmaceutical formulation.

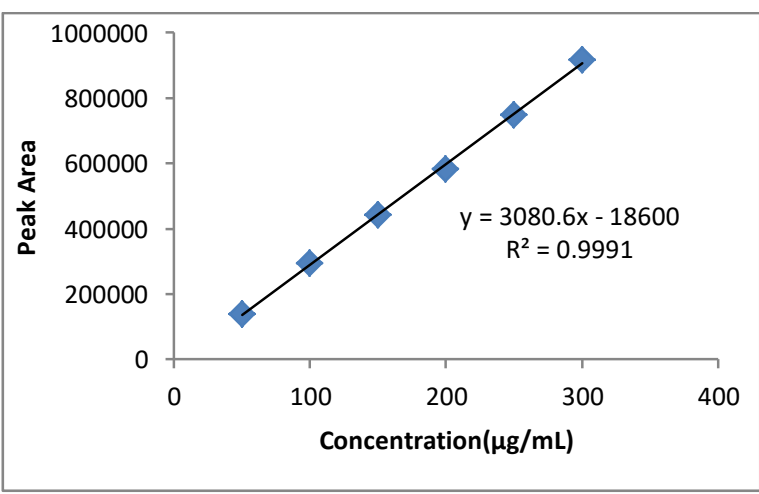

Figure 5: Calibration curve of CEL 
Table 3: Spectral and statistical data for determination of Amlodipine Besylate and Celecoxib by proposed RP-HPLC method.

\begin{tabular}{|ll|ll|}
\hline \multicolumn{4}{|l|}{ Analyte } \\
\hline AML & & CEL & \\
\hline Detection wavelength $(\mathrm{nm})$ & 250 & Detection wavelength $(\mathrm{nm})$ & $50-300$ \\
\hline Linearity range $(\mu \mathrm{g} / \mathrm{ml})$ & $2-12$ & Linearity range $(\mu \mathrm{g} / \mathrm{ml})$ & 0.9991 \\
\hline Coefficient of determination $\left(r^{2}\right)$ & 0.9993 & Coefficient of determination $\left(r^{2}\right)$ & $Y=3080.6 \mathrm{x}-18600$ \\
\hline Regression equation $\left(Y^{\mathrm{a}}\right)$ & $\mathrm{Y}=7486 \mathrm{x}-55$ & Regression equation $\left(\mathrm{Y}^{\mathrm{a}}\right)$ & 3080.6 \\
\hline Slope $(\mathrm{m})$ & 1497.3 & Slope $(\mathrm{m})$ & -18600 \\
\hline Intercept $(\mathrm{c})$ & -55 & Intercept $(\mathrm{c})$ & 0.24 \\
\hline Limit of detection, $\mathrm{LOD}(\mu \mathrm{g} / \mathrm{ml})$ & 0.09 & Limit of detection, $\mathrm{LOD}(\mu \mathrm{g} / \mathrm{ml})$ & 0.75 \\
\hline Limit of quantitation, $\mathrm{LOQ}(\mu \mathrm{g} / \mathrm{ml})$ & 0.29 & Limit of quantitation, $\mathrm{LOQ}(\mu \mathrm{g} / \mathrm{ml})$ & 0.75 \\
\hline
\end{tabular}

a $Y=m x+c$, where $x$ is the concentration $(\mu \mathrm{g} / \mathrm{ml})$

\section{Sensitivity}

The sensitivity of the analytical method was evaluated by determining the limits of detection (LOD) and quantitation (LOQ). The values of LOD and LOQ for AML and CEL are given in Table 3.The low values of LOD and LOQ indicates the sensitivity of method.

\section{Precision}

The \% RSD for intraday and interday precision studies were obtained from three different concentrations $(2,4$ and 6 $\mu \mathrm{g} / \mathrm{ml}$ for AML and 100, 200 and $300 \mu \mathrm{g} / \mathrm{ml}$ for CEL) within linearity range. The $\%$ RSD values for intra-day and inter-day precision were below $1.5 \%$, indicated that the method was sufficiently precise, as shown in Table 4.

Table 4: Precision Studies.

\begin{tabular}{|c|c|c|c|c|c|}
\hline \multirow[t]{2}{*}{ Drug } & \multirow[t]{2}{*}{ Amount $(\mu \mathrm{g} / \mathrm{mL}$} & \multicolumn{2}{|c|}{ Intra-day(n=3) } & \multicolumn{2}{|c|}{ Inter-day(n=3) } \\
\hline & & $\begin{array}{l}\text { Amount found } \\
\text { Mean } \pm \text { SD }\end{array}$ & \%RSD & $\begin{array}{l}\text { Amount found } \\
\text { Mean } \pm \text { SD }\end{array}$ & \%RSD \\
\hline \multirow[t]{3}{*}{$\mathrm{AML}$} & 2 & $1.98 \pm 0.024$ & 1.23 & $2.06 \pm 0.028$ & 1.40 \\
\hline & 4 & $4.02 \pm 0.035$ & 0.89 & $4.09 \pm 0.064$ & 1.63 \\
\hline & 6 & $5.98 \pm 0.056$ & 0.94 & $5.94 \pm 0.067$ & 1.14 \\
\hline \multirow[t]{3}{*}{ CEL } & 100 & $100.12 \pm 0.39$ & 0.39 & $99.74 \pm 0.96$ & 0.97 \\
\hline & 200 & $200.86 \pm 2.26$ & 1.13 & $200.79 \pm 1.46$ & 0.73 \\
\hline & 300 & $299.77 \pm 3.89$ & 1.30 & $299.63 \pm 2.54$ & 0.85 \\
\hline
\end{tabular}

\section{Accuracy}

Accuracy was performed by recovery studies using standard addition method. Standard drugs in the range of 50, 100 and $150 \%$ of the sample concentration were added into the sample solution. Each concentration was analyzed in triplicate. Results of recovery studies were found to be in between 98 to $102 \%$ for both AML and CEL, as shown in Table 5.

Table 5: Recovery studies $(n=3)$.

\begin{tabular}{|l|l|l|l|l|l|l|}
\hline \multirow{2}{*}{ Recovery level } & \multicolumn{3}{|c|}{ AML } & \multicolumn{3}{c|}{ CEL } \\
\cline { 2 - 7 } & $\begin{array}{l}\text { Amount } \\
\text { Added } \\
(\mu \mathrm{g} / \mathrm{ml})\end{array}$ & $\begin{array}{l}\text { Amount } \\
\text { Recovered } \\
(\mu \mathrm{g} / \mathrm{ml})\end{array}$ & $\begin{array}{l}\% \\
\text { Recovery }\end{array}$ & $\begin{array}{l}\text { Amount } \\
\text { Added } \\
(\boldsymbol{\mu g} / \mathbf{m l})\end{array}$ & $\begin{array}{l}\text { Amount } \\
\text { Recovered } \\
(\mu \mathrm{g} / \mathrm{ml})\end{array}$ & $\begin{array}{l}\text { \% } \\
\text { Recovery }\end{array}$ \\
\hline $50 \%$ & 2.5 & 2.49 & 99.62 & 100 & 100.22 & 100.22 \\
\hline $100 \%$ & 5 & 4.99 & 99.80 & 200 & 198.96 & 99.48 \\
\hline $150 \%$ & 7.5 & 7.47 & 99.66 & 300 & 299.25 & 99.75 \\
\hline
\end{tabular}




\section{Robustness}

Robustness study was performed by making small variations in method parameters to assess whether the response is influenced by the small changes. The method parameters investigated in this study are change in the flow rate $( \pm 0.2$ $\mathrm{ml} / \mathrm{min})$, organic composition of mobile phase $( \pm 5 \% \mathrm{v} / \mathrm{v})$ and analytical wavelength $( \pm 2 \mathrm{~nm})$. The results were evaluated by recovery values of analyte solutions. Robustness study showed that variations in flow rate, composition of mobile phase and analytical wavelength do not have a significant effect on the analyte response.The robustness data was shown in Table 6.

Table 6: Chromatographic parameter setting applied in the robustness investigation.

\begin{tabular}{|l|l|l|l|l|l|}
\hline \multirow{2}{*}{ Parameter } & \multirow{2}{*}{ Modification } & \multicolumn{2}{|c|}{ \% Recovery } & \multicolumn{2}{|c|}{ \% RSD } \\
\cline { 2 - 6 } & & AML & CEL & AML & CEL \\
\hline \multirow{5}{*}{ Flow Rate(ml/min) } & 0.9 & 100.20 & 99.64 & 0.67 & 0.88 \\
\cline { 2 - 6 } & 1.0 & 99.92 & 99.38 & 1.21 & 0.94 \\
\cline { 2 - 6 } & 1.2 & 99.45 & 99.82 & 0.82 & 0.55 \\
\hline \multirow{3}{*}{$\begin{array}{l}\text { Mobile Phase } \\
\text { (acetonitile:water) }\end{array}$} & $85: 15 \mathrm{v} / \mathrm{v}$ & 99.74 & 99.34 & 0.84 & 0.71 \\
\cline { 2 - 6 } & $80: 20 \mathrm{v} / \mathrm{v}$ & 99.49 & 99.66 & 0.91 & 0.86 \\
\cline { 2 - 6 } & $75: 25 \mathrm{v} / \mathrm{v}$ & 99.68 & 99.49 & 0.72 & 0.75 \\
\cline { 2 - 6 } & 248 & 99.84 & 99.63 & 0.87 & 1.32 \\
\cline { 2 - 6 } & 250 & 99.92 & 99.71 & 1.25 & 1.01 \\
\cline { 2 - 6 } & 252 & 99.89 & 99.85 & 1.41 & 0.46 \\
\hline
\end{tabular}

\section{Specificity}

Specificity is the ability to unequivocally assess the analyte in the presence of components that may be expected to be present. Typically, these might include impurities, degradants or matrix. Specificity of an analytical method is its ability to accurately and specifically measure the analyte of interest without interference from blank or placebo. The peak purities of AML and CEL were assessed by comparing the retention times of standard AML and CEL and the sample, and good correlation was obtained between the retention time of the standard and sample. Placebo and blank were injected and there were no peaks. There is no interference of degradation peaks on drug peaks hence, the method is specific.

\section{Analysis of commercial formulation}

The proposed method was applied for the determination of Amlodipine Besylate and Celecoxib in marketed formulations available (CONSENSI TABLETS). The \% recovery (Table 7) was found to be $100.08 \pm 0.18$ and $100.25 \pm 0.45$ for Amlodipine Besylate and Celecoxib respectively.

Table 7: Analysis of Amlodipine Besylate and Celecoxib in commercial formulation

\begin{tabular}{|l|l|l|l|l|l|l|}
\hline \multirow{2}{*}{ Formulation } & \multicolumn{2}{|c|}{ Labelled claim(mg) } & \multicolumn{2}{c|}{ Amount found*(mg) } & \multicolumn{2}{c|}{ \%Recovery* \pm RSD } \\
\cline { 2 - 7 } & AML & CEL & AML & CEL & AML & CEL \\
\hline $\begin{array}{l}\text { CONSENSI } \\
\text { TABLETS }\end{array}$ & 5 & 200 & 5.04 & 200.50 & $100.08 \pm 0.18$ & $100.25 \pm 0.45$ \\
\hline
\end{tabular}

*Average of three determinations

\section{CONCLUSION}

The proposed method for the estimation of amlodipine besylate and celecoxib was validated as per the ICH guidelines and it is simple, specific and economical. Furthermore, this simple and rapid RP-HPLC method can also be used successfully for the determination of amlodipine besylate and celecoxib in pharmaceutical formulations without any interference from the excipient.

\section{ACKNOWLEDGEMENT}

The authors thankful to the management of Srikrupa Institute of Pharmaceutical Sciences for providing the instrumental and chemical facilities.
CONFLICT OF INTEREST: There are no Conflicts of interest

\section{REFERENCES}

1. Budavari S. The Merck index: An encyclopedia of chemicals, drugs and biologicals, Merck Research Laboratories, Division of Whitehouse Station, NJ: Merck and Co. Inc, 2001; pp 86.

2. Hardman JG, Limbird LE, Gilman AG. Goodman and Gilman's The Pharmacological Basis of Therapeutics, McGraw Hill, New York, 2001; pp 871.

3. Clemett D, Goa KL, "Celecoxib: a review of its use in osteoarthritis, rheumatoid arthritis and acute pain" Drugs 2000; 59(4):957-80.

4. Mengle-Gaw L, Hubbard RC, Karim A. A study of the platelets effects of SC-58635, a novel selective cox-2 inhibitor. Arthiritis Rheum 1997; 40 Suppl: S93 
5. The Indian Pharmacopoeia, The Controller of Publications, New Delhi, 1996; 72.

6. British Pharmacopoeia, CD-ROM, British Pharmacopoeia, HMSO, London, 2001; 72.

7. Ghule AS, Thomas T, Joseph M, Navya Sree KS, Bhat K, "Simultaneous estimation of telmisartan, hydrochlorothiazide and amlodipine besylate in tablet preparation by chemometric asisted spectrophotometric analysis", Indian Drugs ,2018; 55 (7):59-66.

8. Yadav N, Goyal A, "Simultaneous estimation of aliskiren and amlodipine in combined tablet formulation by simultaneous equation and first derivative spectroscopic methods", Org. Med. Chem. IJ , 2018; 6(1).

9. Usharani N, Divya K, Ashrtiha VVS, "Development and validation of UV Derivative spectroscopic and RP-HPLC methods for the determination of amlodipine besylate and valsartan in tablet dosage form and comparison of the developed methods by student's T-Test", Indian J. Pharmaceu. Edu. Res, 2017; 51(4S):S776-SS82.

10. Mohamed AI, Omar MA, Hammad MA, Mohamed AA, "Development and validation of highly sensitive stability indicating spectrofluorimetric method for determination of amlodipine in pharmaceutical preparations and human plasma", J.Fluoresc, 2016; 26(6):2141-2149.

11. Siridevi PM, Kumar TH, Rao YS, Rao KV, "Simultaneous Spectrophotometric Estimation of Amlodipine Besylate And Perindopril Erbumine In Tablet Formulation". Research Journal of Pharmacy and Technology 2019; 12(12):6101-6105.

12. Jain DK, Jain N, Sharma HK, Jain R, Jain SK, "Development and validation of RP-HPLC method for estimation of amlodipine besylate, olmesartan medoxomil and hydrochlorthiazide in tablet dosage form" . Int J Res Ayurveda Pharm, 2014; 5(4):523530 .

13. Kumar HT, Asha Ch, "New Validated Stability Indicating RP-HPLC Method For Simultaneous Estimation Of Amlodipine Besylate And Valsartan In Pharmaceutical Formulation" Int J Pharm Sci \& Res, 2019; 10(5):2633-43.

14. Kumar HT, Asha Ch, Sankar DG, "Estimation Of Amlodipine Besylate And Irbesartan In Pharmaceutical Formulation By RPHPLC With Forced Degradation Studies" International Journal of Applied Pharmaceutics 2019; 11(33):159-167.

15. Chandran S, Jadhav PR, Kharwade PB, Saha RN " Rapid and sensitive spectrofluorimetric method for the estimation of celecoxib and flurbiprofen", Indian J.Pharm. Sci, 2006; 68 (1):20-25.
16. Dhabu PM, Akamanchi KG, "A stability-indicating HPLC method to determine celecoxib in capsule formulations", Drug. Dev. Indu. Pharm, 2002; 28 (7) :815-821

17. Bapatu HR, Maram RK, Murthy SR, "Stability-Indicating HPLC method for quantification of celecoxib and diacerein along with Its impurities in capsule dosage form ", J. Chromatogr. Sci, 2015; 53 (1):144-153.

18. Hamama AK, Ray J, Day RO, Brien JE, "Simultaneous determination of rofecoxib and celecoxib in human plasma by high-performance liquid chromatography", J. Chromatogr. Sci, 2005; 43(7):351-354.

19. Attimarad M, Narayanswamy VK, Aldhubaib BE, SreeHarsha N, Nair AB, " Development of UV spectrophotometry methods for concurrent quantification of amlodipine and celecoxib by manipulation of ratio spectra in pure and pharmaceutical formulation" PLoS One., 2019; 14(9):21-9

20. Venugopala KN, Aldhubiab BE, Nair AB, SreeHarsha N, Pottathil S, Akrawi SH, "Development of UV Spectrophotometric Procedures for Determination of Amlodipine and Celecoxib in Formulation: Use of Scaling Factor to Improve the Sensitivity", Journal of Spectroscopy, 2019.

21. Mandale TR, Kondawar MS, Kadam SD, "Development and Validation of Analytical Method for Simultaneous Estimation of Amlodipine Besylate and Celecoxib in Pure and Combined Dosage Form" Research J. Pharm. and Tech 2020; 13(9):42804284.

22. Kushwaha D, Diwakar S,RoyRK, Karole S, Kushwaha H, Jain P, "Novel UV Spectrophotometer Methods for Quantitative Estimation of Concensi (Amlodipine 10mg and Celecoxib 200mg) Using Hydrotropic Solubilizing Agents" , Journal of Drug Delivery and Therapeutics. 2019; 9(4-A):651-655

23.Venugopala KN, Aldhubiab BE, Nair AB, SreeHarsha N, Pottathil S, Akrawi SH, "Validation of rapid RP-HPLC method for concurrent quantification of amlodipine and celecoxib in pure and formulation using an experimental design" Microchemical journal, 2020; 152,1-8.

24. Hamid MA, Mabrouk MM, Michael MA, "A fast and green reversed-phase HPLC method with fluorescence detection for simultaneous determination of amlodipine and celecoxib in their newly approved fixed-dose combination tablets" ,Journal of Separation Science, 2020; 43(16):3197-3205.

25. ICH, Q2 (R1). Validation of analytical procedures: text and methodology international conference on harmonization, Geneva, 2005; pp 1-13. 